\title{
MODELLING OF ARTERY STIFFNESS FOR DRIVER'S HEART RATE MONITORING SYSTEMS DEVELOPMENT
}

\author{
Ivan Kernytskyy ${ }^{1 凶}$, Yevheniia Yakovenko², Yevhen Storchun², Orest Horbay ${ }^{2}$, \\ Ruslan Humenyuk ${ }^{3}$, Yaroslav Sholudko ${ }^{3}$ \\ ${ }^{1}$ Institute of Civil Engineering, Warsaw University of Life Sciences - SGGW \\ ${ }^{2}$ Institute of Engineering Mechanics and Transport, Lviv Polytechnic National University \\ ${ }^{3}$ Faculty of Mechanical and Power Engineering, Lviv National Agrarian University
}

\begin{abstract}
Some health complexity happens during driving like heart problem, stroke etc. Driver's health abnormality may also effect safety of other vehicles. So in recent years, automotive manufacturers and users are interested to implement real-time health monitoring in car system. In cardiac monitoring systems, a sensor is an important element. It is not only the type of sensor that determines the correct operation of a system, but also the processing of the registered signals. This paper analyses the influence of the sensor pressing force on the estimation of the stiffness of the artery to describe the pulse signal processing.
\end{abstract}

Key words: driver's health, arteries, modelling of artery stiffness, monitoring systems, pulse diagnosis

\section{INTRODUCTION}

In recent years, new methods and techniques, software and hardware complexes, which combine the ideas of medicine and achievements of Western technologies, have started to appear more often in diagnostic practice.

One of the oldest methods for determining pathological states is pulse diagnosis. For diagnostic purposes it is possible to examine different sections of the arteries, but the pulse diagnosis of radial arteries of wrist joints has the greatest development.

The method of pulse diagnostics is widely universal, it allows to estimate any function of an organism, to predict development of disease in case of non-interference or treatment in one or another way.

Research into the mechanical properties of the arteries - their elasticity, extensibility and ultimate strength - has recently acquired not only theoretical but also clinical and applied significance, as it enables early diagnosis of atherosclerosis, arterial hypertension, assessment of the "relative (biological) age" of blood vessels, cardiovascular risk, disease dynamics and the effect of drug therapy. Some studies investigate, whether pulse signal may be used as an accurate metrics to determine the driver's level of mental workload (Biondi, Coleman, Cooper \& Strayer, 2017).

Clinical evaluation of the elastic properties of the vascular wall is usually performed on large arteries of elastic and muscular elastic type. In particular, the aortic, common carotid femoral and radial artery walls are investigated (Garkavi, Mikhaylov, Tolmachev, Shikhlyarova \& Vereskunova, 2003). 


\section{MATHEMATICAL MODELLING}

Sphygmometry is a graphical method to study the mechanical oscillations of the arterial wall that occur during the transition of the pulse wave. Sphygmogram can be obtained by placing the sensor directly on the place where the pulsating vessel is probed (Milyagin $\&$ Komissarov, 2017). Since the frequency spectrum of the signal in this case is $0.5-40 \mathrm{~Hz}$, the mechanical impedance of biological structures is determined by the elastic properties of the medium and can be characterised by stiffness $\left(K_{a}\right)$. In the work of Garkavi et al. (2003) for the purpose of qualitative evaluation, the elastic properties of the artery wall were modelled by stiffness $\left(K_{a}\right)$ as the following dependence

$$
K_{a}=a_{1}+a_{2} F_{d d}+a_{3} F_{d d}^{2}
$$

where:

$a_{1}, a_{2}, a_{3}$ - polynomic coefficients,

$F_{d d}$ - force value corresponds to the diastolic blood pressure in the artery of the subjects

$$
F_{d d}=\pi L d P_{d}
$$

where:

$L$ - section length in artery,

$d$ - arterial diameter in artery,

$P_{d}-$ pulse pressure in artery (Storchun \& Klymukh, 2012).

Previously in the works (Storchun \& Klymukh, 2012), the form of the radial artery section was considered invariable. In this article, it was accepted that under the influence of sensor pressure, the artery deforms and acquires an elliptical form. It was believed that the length of the ellipse is equal to the length of the circumference of the artery in diastole. Figure 1 shows the stages of the artery section changing. At first, the section takes the form of an ellipse, the eccentricity of which depends on the force of the sensor's pressure on the body surface. Then the cross-sectional area gradually increases due to the action of pulse pressure.

Characterisation $\Delta r$ represents volumetric changes in the artery section size, and the transducer reacts to the movement of the artery wall towards the body surface in the registration area. It is therefore necessary to determine the equivalent movement of the artery wall in this direction. In the case of a circular cross-section, the movement of various sections of the artery wall towards the body surface is as follows $x=\Delta r \cdot \sin \varphi$ (Fig. 2a). For the elliptical form, the movement of the artery wall towards the body surface is calculated using a derivative at the point of the artery surface (Fig. 2b). Figure 3 shows the results of comparing the movement of the artery wall of round (solid line) and elliptical (point) sections.

In the first approximation, the stiffness was determined by expression

$$
K_{a}=\frac{2 \pi r L P_{p u l}}{\Delta r}
$$

where:

$r \quad$ - radius of artery segment,

$L$ - length of artery segment,

$P_{p u l}-$ pulse oscillations of pressure in artery,

$\Delta r-$ pulse radius changing.

Further, calculations of the radial artery stiffness were performed according to the model obtained for the curve (Savytskyy, 1974) shown in Figure 4. Diameter of artery segment was $2 \mathrm{~mm}$ and length was $5 \mathrm{~mm}$.
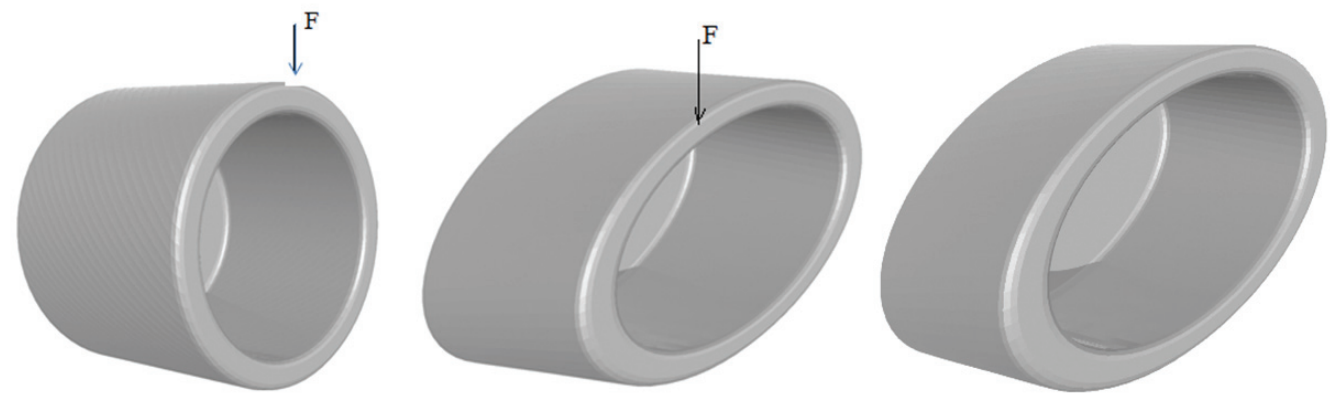

Fig. 1. Artery's section reshaping under the influence of transmural and pulse pressure 
Kernytskyy, l., Yakovenko, Y., Storchun, Y., Horbay, O., Humenyuk, R., Sholudko, Y. (2020). Modelling of artery stiffness for driver's heart rate monitoring systems development. Acta Sci. Pol. Architectura, 19 (3),15-20. doi: 10.22630/ASPA.2020.19.3.23

a

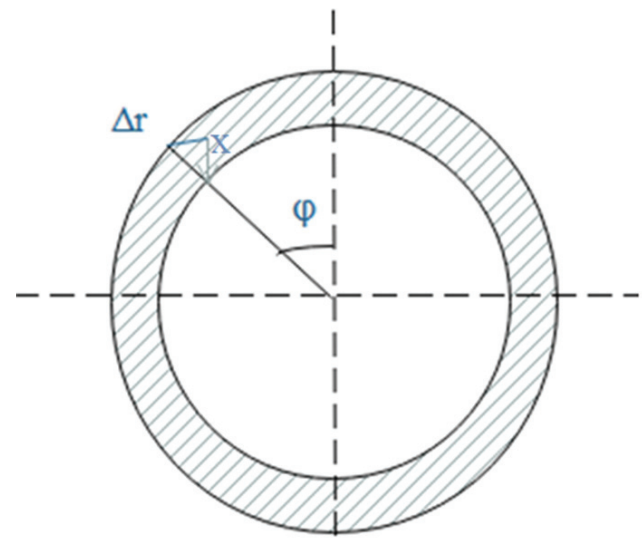

$\mathrm{b}$

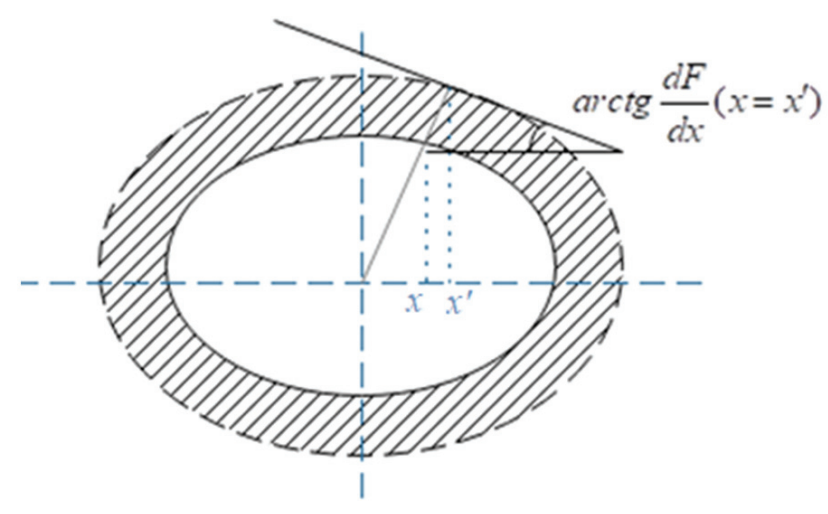

Fig. 2. The equivalent moving of arterial wall

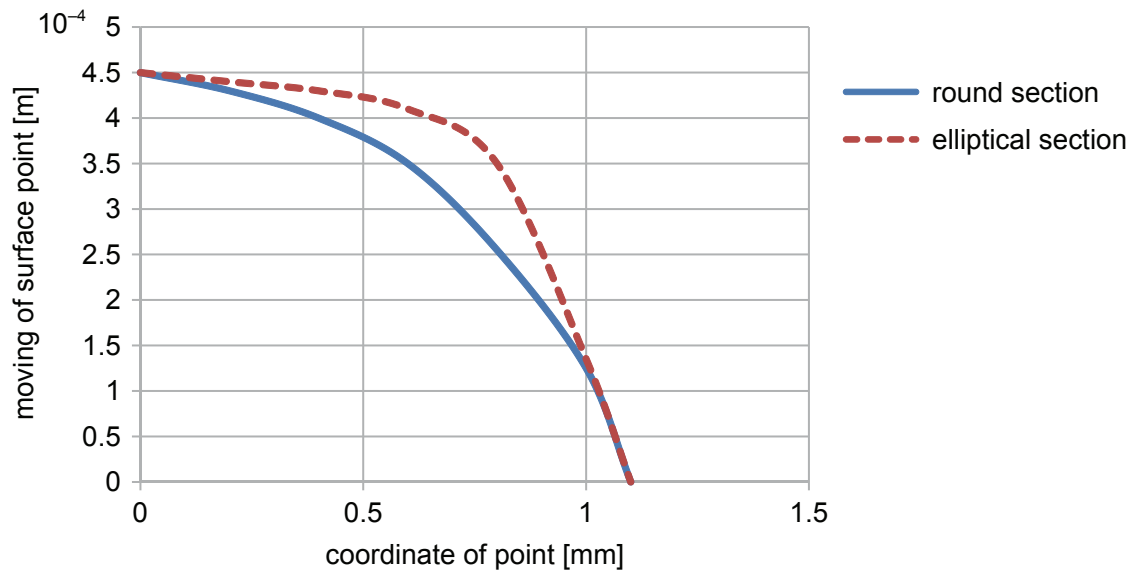

Fig. 3. Moving of every surface point

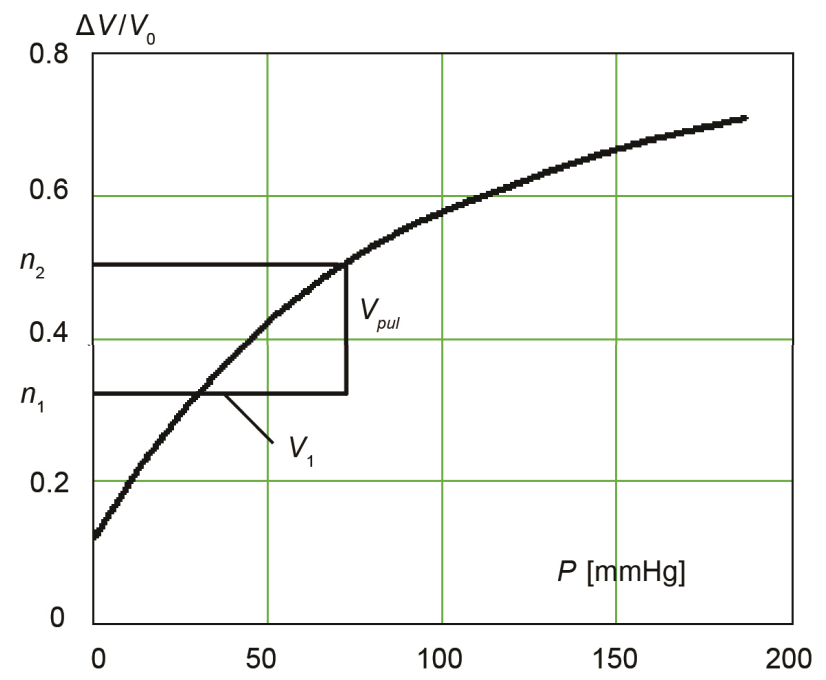

Fig. 4. The dependence of the artery's volume change $(\Delta V)$ relative to the initial volume $\left(V_{0}\right)$ from transmural pressure 
Stiffness of artery segment was calculated using approach from article by Storchun and Klymukh (2012)

$$
K_{a}=2 \pi L \frac{V_{1}}{V_{p u l}} P_{p u l}, \quad \frac{V_{1}}{V_{p u l}}=\frac{1+n_{1}}{n_{2}-n_{1}}
$$

Obtained results were approximated by dependency (1). The calculation was performed for a $5 \mathrm{~mm}$ long artery segment and a pulse pressure value of $40 \mathrm{mmHg}$. The results of the simulation are presented in Figure 5. The solid line corresponds to the case of the artery of round section, dashed-dashed elliptical section with eccentricity 0.05 .

Further, the influence of the magnitude and direction of the sensor's pressure force on the stiffness of the radial artery was investigated. It was accepted that depending on the pressure force, which varies in the range of $0-2 \mathrm{~N}$ eccentricity can take values from 0 to 0.6. Calculation of stiffness was performed for cases where the sensor pressed the artery from the vertical and from the lateral occlusion. Results are presented in Figure 6.

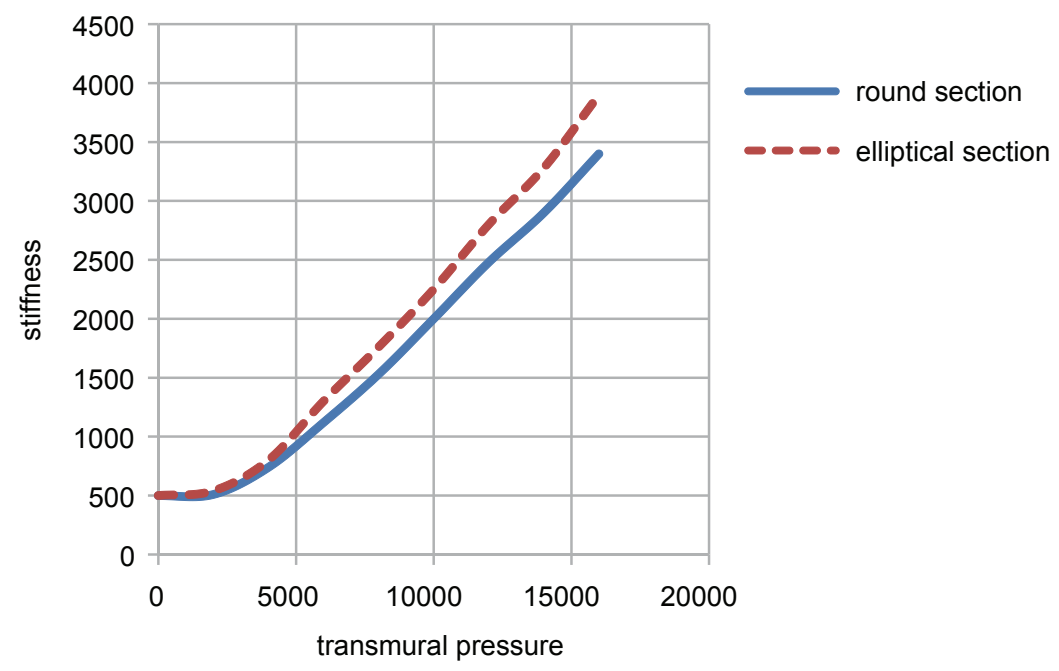

Fig. 5. Dependency of stiffness from transmural pressure

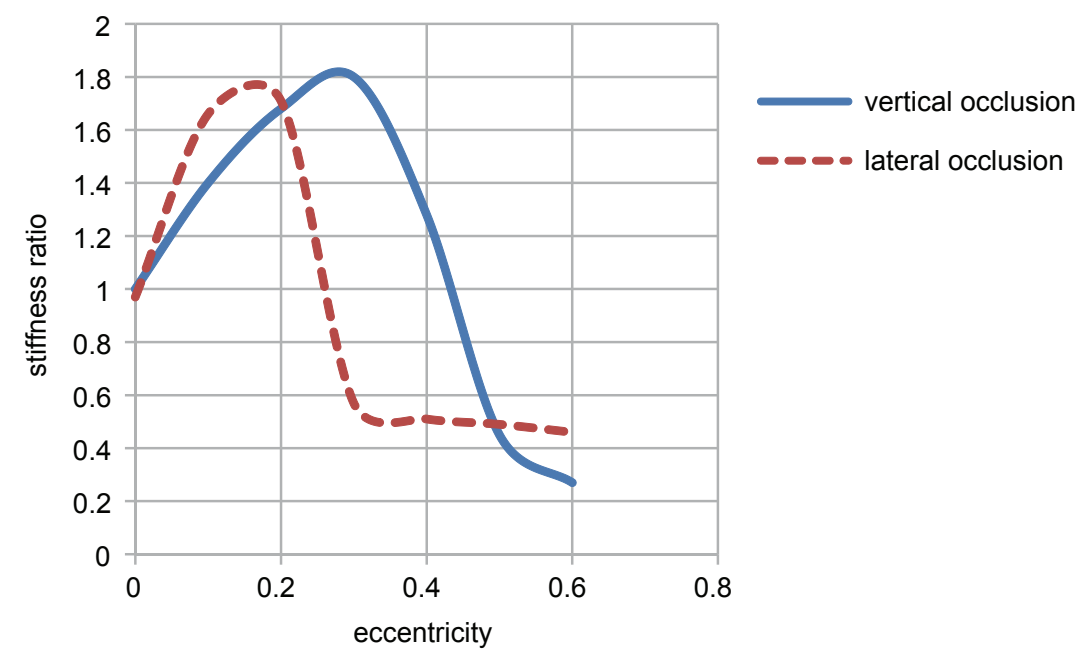

Fig. 6. Stiffness ratio of elliptical and circular artery provided different occlusion of sensor 
Figure 6 shows the dependence of the ratio of stiffness of vascular vessels with a round and elliptical cross-sections as a function of eccentricity of the ellipse. From graphs it is visible, that for the values of eccentricity more than 0.3 for the case of vertical pressure and 0.2 for lateral pressure, which corresponds to the pressure force of the transducer $2-2.5 \mathrm{~N}$ the stiffness of vessels decreases. From this it is possible to draw a conclusion that in the case of significant forces of the transducer pressure the deformation of the artery starts and it is incorrect to use the model to calculate the artery stiffness in the form of the second-degree polynomial function.

\section{CONCLUSIONS}

In this work, a study of radial artery section influence on its stiffness was carried out. It was shown that under relatively small values of sensor pressing force artery section becomes elliptical with eccentricity value of $0.01-0.2$. In this range of values of eccentricity vessel stiffness gradually increases. When the application force exceeds a certain critical value, calculated by the model stiffness value begins to decline sharply. This indicates a change in the elastic properties of arteries. Therefore, to describe the process of forming pulse signal by the force pressing more than $2-2.5 \mathrm{~N}$, depending on the area developed in the works of a mathematical model cannot be applied. It can be useful for car health monitoring system design and development.

\section{Authors' contributions}

Conceptualization: I.K.; methodology: I.K.; software: Y.Y., Y.St.; validation: Y.Y., O.H.; formal analysis: Y.St., R.H.; investigation: Y.Sh.; resources: R.H.; data curation: O.H.; writing - original draft preparation: Y.Y.; writing - review and editing: Y.St., Y.Sh., O.H.; project administration: I.K.; funding acquisition: I.K., R.H., Y.Sh.

All authors have read and agreed to the published version of the manuscript.

\section{REFERENCES}

Biondi, F., Coleman, J., Cooper, J. \& Strayer, D. (2017). Heart Rate Detection for Driver Monitoring Systems. Paper presented at Transportation Research Board 96th Annual Meeting Washington DC, United States, 8-12th January 2017.

Garkavi, L. K., Mikhaylov, N. I., Tolmachev, G. N., Shikhlyarova, A. I. \& Vereskunova, Ye. P. (2003). Programmno-apparatnyy kompleks pulsovoy diagnostiki opredeleniya tipa adaptatsionnoy reaktsii [Hardware and software complex for pulse diagnostics for determining the type of adaptive response]. Elektronnyy zhurnal Issledovano $v$ Rossii, 193, 2295-2303. Retrieved from https://zhurnal.ape.relarn.ru/articles/2003/193.pdf

Milyagin, V. A. \& Komissarov, V. B. (2017). Sovremennyye metody opredeleniya zhestkosti sosudov [Modern methods for determining vascular stiffness]. Arterial'naya gipertenziya - Arterial Hypertension, 16 (2), 134-143.

Savytskyy, N. N. (1974). Biofizicheskie osnovy' krovoobrashheniya i klinicheskie metody' izucheniya gemodinamiki [Biophysical foundations of blood circulation and clinical methods for studying hemodynamics]. Leningrad: Medicina.

Storchun, Y., Klymukh, A. (2012). Modelyuvannya mekhanichnogo impedansu dilyanki arteriyi [Modelling mechanical impedance plots artery]. Visnyk NU L'vivs 'ka politekhnika. Radioelektronikata telekomunikatsiyi, 738, 270-274. 


\section{MODELOWANIE SZTYWNOŚCI ARTERII DLA ROZWOJU SYSTEMÓW MONITOROWANIA TĘTNA KIEROWCY}

\section{STRESZCZENIE}

Pewne dolegliwości zdrowotne występują podczas jazdy, np.: problemy z sercem, udar mózgu itp. Nieprawidłowe zdrowie kierowcy może wpływać na bezpieczeństwo innych pojazdów. W ostatnich latach producenci i użytkownicy motoryzacyjni są zainteresowani wdrożeniem monitorowania stanu zdrowia w czasie rzeczywistym w systemie samochodowym. W systemach monitorowania pracy serca czujnik jest ważnym elementem. Nie tylko rodzaj czujnika determinuje prawidłowe działanie systemu, ale także przetwarzanie zarejestrowanych sygnałów. W pracy przeanalizowano wpływ siły nacisku czujnika na oszacowanie sztywności tętnicy w celu opisania przetwarzania sygnału tętna.

Słowa kluczowe: zdrowie kierowcy, tętnice, modelowanie sztywności tętnic, systemy monitorowania, diagnostyka tętna 